\title{
Uniformity of Impatiens Plug Seedling Growth in Controlled Environments
}

\author{
David R. Dreesen'and Robert W. Langhans ${ }^{2}$ \\ Department of Floriculture and Ornamental Horticulture, Cornell University, Ithaca, NY 14853 \\ Additional index words. Impatiens wallerana, bedding plants
}

\begin{abstract}
Uniformity of growth response of impatiens (Impatiems wallerana Hook. f.) plug seedlings was examined in four identical growth rooms. Differences among growth rooms for dry weight, height, and leaf area of 10- to 24day-old seedlings were generally not significant. During six experiments over 6 months, an individual growth room was maintained under contant baseline environmental conditions. Differences in growth response over time appear to be related to nutrition and irradiance levels. For three experiments with nearly identical irradiance, temperature, and nutrition levels, dry weight and height growth differences over time were only rarely significant. These results illustrate that rather unsophisticated growth rooms can provide consistent growth response over time among experimental units.
\end{abstract}

The production of horticultural crops in CEGR has not been adopted by commercial growers except for a few examples of vegetable seedling production (Buck, 1973; Canham, 1971), large-scale hydroponic vegetable production (Miller, 1989), and production of asexual propagules using tissue culture techniques. The high operating and capital costs of CEGR constrain the types of crops that might be profitably grown. The criteria that must be satisfied by a crop to be profitably produced in CEGR include: 1) a high crop value per unit of production area; 2) a short production period; 3) a major enhancement in growth due to the environmental conditions provided by CEGR; and 4) improved quality for plant materials produced under CEGR conditions. Plug seedlings of annual bedding plants meet the first two criteria with crop values for one rotation of about $\$ 100$ (U.S.) $/ \mathrm{m}^{2}$ [i.e., individual seedling value between $\$ 0.03$ to $\$ 0.05$ (U.S.)] and greenhouse production schedules as short as several weeks for some species.

The accelerated growth of bedding plant (Krizek et al., 1968) and vegetable seedlings (Krizek et al., 1974) was shown in these early studies using controlled environment chambers. These studies produced seedlings that were 10 to 44 times heavier than seedlings produced under greenhouse conditions. By increasing the irradiance, temperature, and $\mathrm{CO}_{2}$ level in the chambers to levels higher than normal, dry weight, leaf area, and number of leaves increased significantly. In addition, precocious flower bud formation and increased lateral branch growth were found under these more optimum environments.

The present study was part of a project to comprehensively address the growth response of seedlings produced in CEGR. Experiments were conducted to examine the uniformity of growth response over time and among CEGR as part of the larger study investigating the growth of seedlings in response to various temperature, irradiance, and $\mathrm{CO}_{2}$ levels (Dreesen, 1988).

Two experimental design considerations that should be addressed initially when conducting research in growth rooms or growth chambers relate to the uniformity of plant response if 1) similar conditions are maintained among a set of CEGR, and

Received for publication 12 Oct. 1990. Research funded by New York State Dept. of Agriculture and Markets. Equipment and supplies donated by Ivy Acres Inc., BFG Supply Co., Harris Moran Seed Co., Ball Seed Co., H.G. German Seed Co., Vaughans Seed Co., and W.R. Grace Co. The cost of publishing this paper was defrayed in part by the payment of page charges. Under postal regulations, this paper therefore must be hereby marked advertisement solely to indicate this fact.

'Former graduate research assistant, currently research associate. ${ }^{2}$ Professor.
2) similar conditions are imposed in a series of experiments over time. Hammer et al. (1978) concluded from lettuce baseline growth studies that it is necessary to repeat growth chamber experiments over time to estimate experimental error. To address both of these concerns, the initial experiment was devoted to assessing growth uniformity among four growth rooms maintained at nearly identical baseline environmental conditions. In each subsequent experiment, one CEGR was maintained at baseline conditions to track growth response over time.

\section{Materials and Methods}

Growth rooms. Four growth rooms (3.4 m long, $2.5 \mathrm{~m}$ wide, and $2.2 \mathrm{~m}$ high) were constructed in two blacked-out greenhouse sections; each room was of wood frame construction with an interior of galvanized steel sheet painted white. The lighting system in the ceiling of each CEGR consisted of 15 Power Groove (F96 PG17/CW -215 W; General Electric, Hendersonville, N. C.) cool-white fluorescent lamps mounted $76 \mathrm{~mm}$ oncenter (i.e., $22 \mathrm{~mm}$ between lamps) in a $1.3 \times 2.5 \mathrm{~m}$ frame covered with a $0.1 \mathrm{~mm}$ Tedlar polyvinylfluoride thermal barrier. The distribution of irradiance from the lighting system design was symmetrical. The four corners of the growing bench (1.2 $\mathrm{x} 2.4 \mathrm{~m}$ ) received $\mathrm{LI}$, while $\mathrm{HI}$ was measured in the four central plug tray positions. The irradiance levels at the tray positions along the edges were denoted MHI and MLI. Details on levels of photosynthetic photon flux (PPF) obtained at these tray positions are reported in the Results section.

In each CEGR, two small fans (each with a flow rate of 0.06 $\mathrm{m}^{3} \cdot \mathrm{s}^{-1}$ ) exhausted room air; a slotted air inlet was installed at floor level to provide entry of cooler greenhouse air. If the greenhouse section was maintained at $13 \mathrm{C}$, the CEGR could be maintained at $18 \mathrm{C}$ by conductive and radiative heat loss with no mechanical ventilation. If necessary, heat could be supplied by a $1500-W$ electric unit heater in each CEGR. The exhaust fans and heaters were controlled by a computerized environmental control and data acquisition system (Keithley System 500, Cleveland). Air temperatures were measured with an aspirated solid state sensor (constant current source integrated circuit). Two additional temperature sensors in each CEGR were inserted into the plug medium at two tray positions (HI and LI) representing irradiance extremes.

\footnotetext{
Abbreviations: CEGR, controlled environment growth rooms; HI, high irradiante levels; LI, low irradiance levels; MHI, medium high irradiance levels; MLI, medium low irradiance levels
} 
The seedling trays were placed on an ebb and flood bench ( $2.4 \mathrm{~m}$ long and $1.2 \mathrm{~m}$ wide with $0.1 \mathrm{~m}$ rim height) in each CEGR. The bench was flooded daily for 45 rein; the nutrient solution drained back to a 210-liter polyethylene reservoir for use again in the recirculating irrigation system. The plug trays were supported on a polyvinylchloride pipe framework placed in each bench. This support system allowed 1) any roots emerging from the plug tray drain holes to be air-pruned in the 20$\mathrm{mm}$ air space between the bottom of the trays and the surface of the bench, and 2) the bottom $20 \mathrm{~mm}$ of the trays to be submerged when the bench was flooded. The bench could accommodate 16 seedling trays $(.0 .53 \mathrm{~m}$ long and $0.27 \mathrm{~m}$ wide) in a four tray $\times$ four tray arrangement.

Seedling culture. The impatiens cultivar selected, 'Accent Red', was one of the major cultivars being sold in the late 1980s. The seed was selected and graded by the seed company to provide high germination percentages (97\% to $99 \%$ ) and uniform germination time.

The plug trays contained 512 tapered square cells. Each cell had a volume of $3 \mathrm{~cm}^{3}$, an opening $13 \times 13 \mathrm{~mm}$, and was 25 $\mathrm{mm}$ deep; the tray had 32 rows each with 16 cells. The plug trays were filled with a dry commercial peat moss and vermiculite medium (Terra-Lite Vegetable Plug Mix, W.R. Grace, Cambridge, Mass.), compressed, and refilled. One lot of mix was used in the course of seven experiments (about one bag per experiment); appreciable differences in the nutrient charge were found between bags. A 1:5 medium to acetic acid extract of composite samples from each bag showed some bags with moderate $\mathrm{NO}_{3}^{-}-\mathrm{N}$ and $\mathrm{K}$ levels (9 to $14 \mathrm{mg} \mathrm{N} / \mathrm{liter}$ and 27 to 38 $\mathrm{mg} \mathrm{K} /$ liter) and other bags with little nutrient charge (1 to $3 \mathrm{mg}$ $\mathrm{N} /$ liter and 8 to $12 \mathrm{mg} \mathrm{K} /$ liter). Other major and minor nutrients were more uniformly distributed, indicating that limestone and minor nutrient additions were fairly consistent between bags; media extracts ranged from (mg element/liter) 43 to 79 for $\mathrm{Ca}$, 25 to 35 for $\mathrm{Mg}, 0.2$ to 0.3 for $\mathrm{Mn}$, and 0.29 to 0.47 for $\mathrm{Fe}$. The inconsistency in $\mathrm{N}$ and $\mathrm{K}$ level caused us to increase nutrient concentrations in the irrigation water after the initial experiment to reduce the effects of nonuniform nutrient charges.

The seed was sown with a compressed-air operated vacuum seeder (Hamilton Natural Seeder, Burnham, England); adjustments on the seeder were used to achieve high percentages of cells with a single seed per cell. After sowing, the trays were subirrigated to saturation, misted, and then transferred to the germination chamber. In the initial experiment, germination was carried out in a dark chamber maintained at $25 \mathrm{C}$ and very high relative humidity from a continuously operating ultrasonic humidifier. More rapid and uniform germination was obtained when seeds were exposed to light. Therefore, in subsequent experiments, germination was carried out in each CEGR under a polyethylene cover over the ebb and flood bench. The environmental conditions maintained under the cover during the germination phase were high relative humidity, moderate photosynthetic photon flux (PPF of 200 to $300 \mu \mathrm{mol} \cdot \mathrm{m}^{-2} \cdot \mathrm{s}^{-1}$ ), 24-h photoperiod, air between 24 and $26 \mathrm{C}$, and daily subirrigation with tap water. The cover was left in place until 4 days after sowing when radicles had emerged from the majority of seed.

At the end of the germination period, nutrient stock solution was added to the water reservoir. The mean nutrient concentrations (in mg element/liter) for the four CEGR at the start of the initial experiment were $110 \mathrm{NO}_{3}^{-}-\mathrm{N}, 49 \mathrm{P}, 118 \mathrm{~K}, 137 \mathrm{Ca}$, $0.31 \mathrm{Fe}, 0.12 \mathrm{Zn}, 0.05 \mathrm{~B}, 0.04 \mathrm{Mn}, 0.03 \mathrm{Cu}$, and 0.01 Mo. Because of the inconsistent nutrient charges among bags of medium, the initial nutrient concentrations (except P) were in- creased by $25 \%$ to $30 \%$ in the second experiment and by another $35 \%$ to $45 \%$ in subsequent experiments. Throughout the course of each individual experiment (20 to 25 days), additional nutrients were not added to replenish uptake losses. However, phosphoric acid was added periodically to maintain the solution $\mathrm{pH}$ between 5.5 and 6.5 ; the resulting solution concentration was generally between 40 and $60 \mathrm{mg}$ P/liter. Tap water was periodically added to the reservoirs to replenish evapotranspiration.

Sampling and data collection. Sampling in the first experiment was at 6-day intervals, starting 11 days (Day 11) after sowing. In later experiments, the sampling interval was 3 days, starting at Day 10 when most of the cotyledons were fully expanded. Sampling for seedling dry weight and height was performed on the LI and HI trays 1 day before the MLI and MHI trays. Leaf area samples were taken the following day.

The seedling sampling procedure was developed to address the following considerations: 1) all seedlings on the outside edge of the block to be sampled were eliminated to reduce edge effects; 2) the number of rows of cells sampled depended on the size of the seedlings; for example, six rows were sampled from each tray to provide sufficient numbers (from 55 to 75 seedlings) to obtain an adequate dry weight sample on Day 10; 3 ) the rows to be sampled were from opposite ends of the tray because of the gradation of irradiance over a tray (i.e., the average of irradiance levels at the two end rows was equivalent to the irradiance at the tray midpoint); 4) seedlings were harvested only if there was one seedling per cell and it was not obviously abnormal; the number of cells with single seedlings, multiple seedlings, or no seedlings was recorded; 5) usually six to eight seedlings were selected at random from the dry weight sample for height measurements; the height was measured from the stem cut at the medium surface to the swollen petiole on the uppermost set of leaves. The mean seedling dry weight for each tray was determined from the total dry weight divided by the number of seedlings sampled. One or two rows of seedlings were sampled from near the middle of each tray for leaf area measurement; typical sample sizes were $\approx 10$ and 25 seedlings for 19-day-old and 10-day-old seedlings, respectively. The leaf area of a sample was determined with a LI-COR3100 area meter (LI-COR, Lincoln, Neb.); the mean leaf area of seedlings from an individual tray was determined by dividing the total sample leaf area by the number of seedlings in the sample. The mean height was determined from measurements of six to eight seedlings from each tray at each sampling.

Data analysis. The treatment means for seedling dry weight and height represent the mean of three replicate trays from the same irradiance level in each CEGR. The mean leaf area for a treatment represents a sample from only one tray from each irradiance level in each CEGR. Least significant differences (LSD) were calculated only when significant treatment effects $(\mathrm{P}<0.05)$ were evident from the analysis of variance (ANOVA) (Sokal and Rohlf, 1969; Snedecor and Cochran, 1980). ANOVA was performed using Minitab statistical software (Minitab, 1988).

Experiment design-growth room uniformity (Expt. I). The first experiment was conducted to investigate whether intrinsic differences between growth room would result in significantly different growth response when nearly identical environmental conditions were imposed. This set of conditions was termed baseline, because in each of the later experiments one CEGR was maintained at these same conditions. The baseline settings were as follows: $24 \mathrm{~h}$ continuous lighting, $9 \mathrm{~h}$ day temperature, 
$15 \mathrm{~h}$ night temperature, $18 / 23 \mathrm{C}$ night/day heating set points, $19 / 24 \mathrm{C}$ night/day cooling set points, and ambient $\mathrm{CO}_{2}$. The mean air and plug medium temperatures that were obtained in the CEGR are reported in the Results section (see Table 1). The baseline PPF was fixed by a lamp to plug tray distance of 0.61 $\mathrm{m}$ and resulted in PPF values of $23 Q \mathrm{er} \mathrm{mol} \cdot \mathrm{m}^{-2} \cdot \mathrm{s}^{-1}$ at the LI and $360 \mu \mathrm{rmol} \cdot \mathrm{m}^{-2} \cdot \mathrm{s}^{-1}$ at the HI. In one CEGR (growth room D), PPF was $10 \%$ lower as a result of using older lamps. The PPF was measured at all tray midpoints (i.e., 16 points in each CEGR) using a LI-COR 185 irradiance meter and quantum sensor at the beginning and end of each experiment. The PPF at the tray midpoint was found to be equal to the mean of $18 \mathrm{PPF}$ measurements taken on a sampling grid of an individual plug tray.

Experiment design-uniformity over time (Expts. I-W). In each experiment after Expt. I, one growth room was maintained at the baseline conditions to track growth response over time. This set of six experiments was conducted over $\approx 6$ months (mid-September to early March).

\section{Results and Discussion}

Uniformity among growth rooms. The temperature differences among growth rooms having the maximum and minimum mean air temperatures were $0.4 \mathrm{C}$ and $0.6 \mathrm{C}$ for day and night set points, respectively (Table 1). The larger standard error for night than for day temperatures probably resulted from high ambient night temperatures in the surrounding greenhouse during the course of Expt. I (conducted in mid-September), making temperature control more problematic. The mean night air temperatures were 0.3 to $0.9 \mathrm{C}$ higher than the cooling set point; the mean day air temperatures were about equal to the midpoint between the heating and cooling set points (i.e., 23.5 C). The plug medium was up to $\mathrm{IC}$ warmer than the air at the $\mathrm{LI}$ and up to $2 \mathrm{C}$ warmer at the $\mathrm{HI}$.

A trend of lower air and plug medium temperatures in growth room D may reflect the lower irradiance levels in this CEGR (Table 2). Examination of the mean PPF at the four irradiance levels shows the following order of PPF values among rooms: $\mathrm{B}>\mathrm{A}>\mathrm{C}>\mathrm{D}$. The distinctly lower PPF in room D probably resulted from older fluorescent lamps. Differences in PPF among the other CEGR are probably also due to variation in lamps or ballast performance; the dimensions (e.g., bench to lamp distance) and lamp arrangement were identical among CEGR.
The concentrations of nutrients in the solution were similar among CEGR both at the start and at the end of the experiment (Table 3) as shown by the standard deviations. The percentage of the initial nutrients taken up by the plants and media ranged from $23 \%$ to $55 \%$.

The seedling stands were similar in all growth rooms, with $79 \%$ to $83 \%$ of tray cells having single, normal seedlings and $5 \%$ to $8 \%$ of tray cells having multiple seedlings.

ANOVA of seedling dry weight showed significant $(\mathrm{P}<$ 0.05) differences among CEGR during the course of the experiment for only three of 12 ANOVAS. Treatment (i.e., growth room) effects on seedling height were significant for two of 12 ANOVAs (Table 4). The standard error of the seedling height was between 0.2 and $0.4 \mathrm{~mm}$ for all ages and irradiance levels, except for HI seedlings on Day 17 and Day 23. In contrast, the standard error of the dry weight tended to increase with seedling age.

The mean dry weights that were significantly different among growth rooms (Table 5) show heavier seedlings in rooms B and $C$ than in the others. This trend may reflect the high PPF in room $\mathrm{B}$, intermediate $\mathrm{PPF}$ in rooms $\mathrm{A}$ and $\mathrm{C}$, and low PPF in room $\mathrm{D}$. Conversely, the height data show room $\mathrm{B}$, with high PPF, having shorter seedlings, which is consistent with data from later experiments showing height reduction with increasing PPF during the early growth stage of impatiens seedlings (Dreesen, 1988). Because no replicate leaf area measurements were made within irradiance levels in each growth room, ANOVA required the pooling of data among irradiance levels to test differences between growth rooms. The seedling leaf area observed in room $D$ was significantly $(\mathrm{P}<0.05)$ smaller than leaf area of seedlings from rooms A and B on Day 14; mean seedling leaf areas were 191, 192, 177, and $143 \mathrm{~mm}^{2}$ for growth rooms A, B, C, and D, respectively. This trend may again reflect the lower PPF in room D. The leaf area of seedlings sampled on Day 20 and Day 26 was not significantly different among growth rooms.

In conclusion, most characteristics of seedling growth revealed no significant effect of particular growth rooms on dry weight, height, and leaf area growth under baseline environmental conditions. For those few instances where significant differences were found, it appears that the nonuniform PPF among the growth rooms may be the cause. Later experiments showed the influence of PPF on shoot dry weight, height, and leaf area growth (Dreesen, 1988).

Table 1. Mean air and plug medium temperatures in the four growth rooms used for Expt. I. Mean temperatures based on 23 daily means of 15 -min average temperature (except $\mathrm{HI}$ day maximum with $\mathrm{n}=6)$.

\begin{tabular}{lccccc}
\hline \hline $\begin{array}{l}\text { Temperature } \\
\text { measured } \\
\text { \{setpoints heating/ } \\
\text { cooling\} }\end{array}$ & $\begin{array}{c}\text { Growth room } \\
\text { with minimum } \\
\text { mean temp } \\
\left({ }^{\circ} \mathrm{C}\right)\end{array}$ & $\begin{array}{c}\text { SE of } \\
\text { mean }\end{array}$ & $\begin{array}{c}\text { Growth room } \\
\text { with maximum } \\
\text { mean temp } \\
\left({ }^{\circ} \mathrm{C}\right)\end{array}$ & $\begin{array}{c}\text { SE of } \\
\text { mean }\end{array}$ & $\begin{array}{c}\text { Difference } \\
\text { between } \\
\text { maximum and } \\
\text { minimum }\left({ }^{\circ} \mathrm{C}\right)\end{array}$ \\
\hline $\begin{array}{l}\text { Air } \\
\quad \text { Night }\{18 / 19\}\end{array}$ & $19.3(\mathrm{D})^{z}$ & 0.2 & $19.9(\mathrm{~A})$ & 0.2 & 0.6 \\
$\quad$ Day $\{23 / 24\}$ & $23.2(\mathrm{D})$ & 0.1 & $23.6(\mathrm{~B})$ & 0.1 & 0.4 \\
HIy plug medium & & & & & 0.3 \\
$\quad$ Night & $21.1(\mathrm{D})$ & 0.3 & $21.4(\mathrm{~B})$ & 0.3 & 0.6 \\
$\quad$ Day & $23.9(\mathrm{D})$ & 0.2 & $24.5(\mathrm{~A})$ & 0.2 & 0.8 \\
LIy plug medium & & & & & 0.2 \\
$\quad$ Night & $20.0(\mathrm{~B})$ & 0.2 & $20.8(\mathrm{C})$ & 0.2 & 0.1 \\
$\quad$ Day & $22.9(\mathrm{~B})$ & 0.2 & $23.3(\mathrm{C})$ & 0.1 & \\
\hline
\end{tabular}

${ }^{\mathrm{z}}$ In parentheses - growth room with minimum or maximum temperature.

${ }^{y} \mathrm{HI}$ tray position, LI tray position. 
Table 2. Mean photosynthetic photon flux in the four growth rooms at the end of Expt. I (four observations per mean).

\begin{tabular}{lccccr}
\hline \hline & \multicolumn{5}{c}{$\begin{array}{c}\text { Mean photosynthetic photon flux } \\
\left(\mu \mathrm{mol} \cdot \mathrm{m}^{-2} \cdot \mathrm{s}^{-1}\right)^{\mathbf{z}}\end{array}$} \\
\cline { 2 - 5 } Irradiance & \multicolumn{5}{c}{ Growth room } \\
nevel & $\mathrm{A}$ & $\mathrm{B}$ & $\mathrm{C}$ & $\mathrm{D}$ & LSD $^{\mathbf{y}}$ \\
\hline High & 341 & 360 & 332 & 302 & 6 \\
Medium high & 286 & 296 & 276 & 254 & 7 \\
Medium low & 258 & 272 & 252 & 231 & 11 \\
Low & 220 & 229 & 215 & 198 & 10 \\
\hline \hline
\end{tabular}

${ }^{2}$ Mean based on irradiance measurements at the midpoint of four tray locations within each irradiance level in each growth room.

${ }^{y}$ Least significant difference calculated for significantly different irradiance among growth rooms (ANOVAs $P<0.001$ ) within each irradiance level.

Table 3. Mean nutrient concentrations in irrigation solutions in the four growth rooms at the start and end of Expt. I and percentage of initial concentration remaining at the end of the experiment.

\begin{tabular}{|c|c|c|c|c|c|}
\hline \multirow[b]{3}{*}{ Nutrient } & \multicolumn{4}{|c|}{ Concn $\left(\mathrm{mg} \cdot \mathrm{liter}^{-1}\right)$} & \multirow{3}{*}{$\begin{array}{c}\text { Remaining } \\
\text { concn } \\
(\%)\end{array}$} \\
\hline & \multicolumn{2}{|c|}{ Start } & \multicolumn{2}{|c|}{ End } & \\
\hline & Mean $^{z}$ & SD & $\operatorname{Mean}^{2}$ & SD & \\
\hline $\mathrm{NO}_{3}^{-}-\mathrm{N}$ & 109 & 5 & 62 & 2 & 57 \\
\hline PY & 49 & 2 & 27 & 1 & 55 \\
\hline $\mathrm{K}$ & 118 & 2 & 75 & 3 & 64 \\
\hline $\mathrm{Ca}$ & 137 & 1 & 105 & 2 & 77 \\
\hline $\mathrm{Fe}$ & 0.31 & 0.01 & 0.14 & 0.01 & 45 \\
\hline $\mathrm{pH}^{\mathrm{y}}$ & 6.3 & & 7.4 & & \\
\hline
\end{tabular}

${ }^{z}$ Mean concentration based on analysis of nutrient solutions from each of the four growth rooms.

y No additional $\mathrm{H}_{3} \mathrm{PO}_{4}$ was added after the start of the experiment for acidification.

Table 4. Mean and standard error of impatiens seedling shoot dry weights and heights for the four growth rooms under baseline conditions.

\begin{tabular}{lccccccc}
\hline \hline $\begin{array}{l}\text { Seedling } \\
\text { age } \\
\text { (days) }\end{array}$ & $\begin{array}{c}\text { Irradi- } \\
\text { ance } \\
\text { level }\end{array}$ & $\begin{array}{c}\text { Mean } \\
(\mathrm{mg})\end{array}$ & $\begin{array}{c}\mathrm{SE}^{\mathrm{z}} \\
(\mathrm{mg})\end{array}$ & $\begin{array}{c}\mathrm{LSD}^{\mathrm{y}} \\
(\mathrm{mg})\end{array}$ & $\begin{array}{c}\text { Mean } \\
(\mathrm{mm})\end{array}$ & $\begin{array}{c}\mathrm{SE}^{\mathrm{z}} \\
(\mathrm{mm})\end{array}$ & $\begin{array}{c}\mathrm{LSD}^{y} \\
(\mathrm{~mm})\end{array}$ \\
\hline 11 & $\mathrm{LI}$ & 1.8 & 0.1 & 0.2 & 7.2 & 0.3 & $\mathrm{NS}$ \\
& $\mathrm{HI}$ & 2.2 & 0.03 & NS & 6.8 & 0.3 & NS \\
12 & MLI & 3.0 & 0.1 & NS & 8.1 & 0.4 & NS \\
& MHI & 2.9 & 0.2 & NS & 8.0 & 0.3 & 0.5 \\
17 & LI & 11.3 & 1.0 & 1.7 & 11.1 & 0.2 & NS \\
& HI & 15.3 & 0.8 & NS & 11.7 & 1.0 & 2.0 \\
18 & MLI & 15.7 & 0.5 & NS & 12.6 & 0.2 & NS \\
& MHI & 16.0 & 0.5 & NS & 13.4 & 0.2 & NS \\
23 & LI & 28.3 & 1.2 & NS & 18.3 & 0.3 & NS \\
& HI & 38.5 & 0.6 & NS & 18.9 & 0.9 & NS \\
24 & MLI & 39.1 & 0.4 & NS & 20.2 & 0.2 & NS \\
& MHI & 39.8 & 1.2 & 2.1 & 20.9 & 0.3 & NS \\
\hline \hline
\end{tabular}

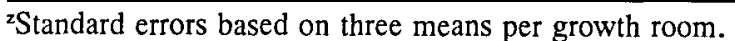

${ }^{y}$ Least significant difference $(P=0.05)$ when treatment effect (growth room) was significant at $P<0.05$ from ANOVA.

Uniformity of growth over time. Irradiance levels were lower in Expts. III, IV, and V than in Expts. I and II (see Table 6). The large increase in PPF in Expt. VI resulted from the installation of new lamps in all growth rooms.

The nutrient concentrations were increased after Expts. I and 11 because of the nonuniform nutrient charges in the plug medium (see Materials and Methods). Consistent initial nutrient
Table 5. Shoot dry weight and height of impatiens seedlings in the four growth rooms that show significant $(P<0.05)$ differences among rooms.

\begin{tabular}{lcccccc}
\hline \hline \multirow{2}{*}{$\begin{array}{l}\text { Seedling } \\
\text { age } \\
\text { (days) }\end{array}$} & $\begin{array}{c}\text { Irradiance } \\
\text { level }\end{array}$ & $\mathrm{A}$ & $\mathrm{B}$ & $\mathrm{C}$ & $\mathrm{D}$ & LSD \\
\cline { 3 - 6 } & & \multicolumn{5}{c}{ Gry wt $(\mathrm{mg})$} \\
11 & LI & 1.57 & 1.97 & 2.00 & 1.77 & 0.18 \\
17 & LI & 10.2 & 11.6 & 13.5 & 9.7 & 1.7 \\
24 & MHI & 38.7 & 42.5 & 40.5 & 37.6 & 2.1 \\
& & \multicolumn{5}{c}{$H t(m m)$} \\
12 & MHI & 8.43 & 7.43 & 8.10 & 8.17 & 0.52 \\
17 & HI & 11.3 & 9.5 & 13.3 & 12.7 & 2.0 \\
\hline \hline
\end{tabular}

Table 6. Irradiance, nutrient level, and air and plug medium temperature maintained in Expts. I-VI for growth rooms at baseline environmental conditions.

\begin{tabular}{|c|c|c|c|c|c|c|}
\hline \multirow[b]{2}{*}{ Variable } & \multicolumn{6}{|c|}{ Experiment no. } \\
\hline & I & II & III & IV & V & $\mathrm{VI}$ \\
\hline $\begin{array}{l}\text { Irradiance } \\
\text { level }\end{array}$ & \multicolumn{6}{|c|}{$P P F\left(\mu \mathrm{mol} \cdot \mathrm{m}^{-2} \cdot \mathrm{s}^{-1}\right)$} \\
\hline LI & 225 & 230 & $210^{\prime \prime}$ & 215 & 210 & 275 \\
\hline $\mathrm{HI}$ & 350 & 360 & 315 & 325 & 310 & 420 \\
\hline Nutrient & \multicolumn{6}{|c|}{ Initial solution concn (mg-liter $\left.{ }^{-1}\right)$} \\
\hline $\mathrm{NO}_{3}^{-}-\mathrm{N}$ & 110 & 141 & 186 & 193 & 198 & 192 \\
\hline $\mathrm{K}$ & 118 & 143 & 211 & 210 & 211 & 200 \\
\hline $\mathrm{Ca}$ & 137 & 168 & 213 & 195 & 205 & 198 \\
\hline$P$ & 49 & 54 & 51 & 51 & 50 & 49 \\
\hline $\mathrm{Fe}$ & 0.31 & 0.40 & 0.51 & 0.55 & 0.57 & 0.56 \\
\hline & \multicolumn{6}{|c|}{ Final solution concn $\left(\mathrm{mg} \cdot \mathrm{liter}^{-1}\right)$} \\
\hline $\mathrm{NO}_{3}^{-}-\mathrm{N}$ & 78 & 86 & 134 & 164 & 160 & 119 \\
\hline $\mathrm{K}$ & 89 & 105 & 162 & 169 & 176 & 129 \\
\hline $\mathrm{Ca}$ & 119 & 125 & 176 & 167 & 180 & 137 \\
\hline $\mathrm{P}^{\mathrm{z}}$ & 34 & 45 & 59 & 39 & 58 & 47 \\
\hline $\mathrm{Fe}$ & 0.17 & 0.14 & 0.26 & 0.32 & 0.30 & 0.30 \\
\hline
\end{tabular}

Mean temp $\left({ }^{\circ} \mathrm{C}\right)$

\begin{tabular}{llllrrr} 
& \multicolumn{7}{c}{ Air } \\
Night & 19.7 & 18.6 & 18.6 & 18.9 & 18.9 & 18.5 \\
Day & 23.4 & 23.0 & 23.0 & 23.1 & 23.1 & 23.0 \\
& & \multicolumn{5}{c}{ Plug } \\
HI night & 21.2 & 21.2 & 21.3 & 20.3 & 20.8 & 20.7 \\
HI day & 24.3 & 24.0 & 23.9 & 22.8 & 23.5 & 22.8 \\
LI night & 20.5 & 19.9 & 19.9 & 19.7 & 20.5 & 19.6 \\
LI day & 23.1 & 22.6 & 22.2 & 21.9 & 22.7 & 22.2 \\
\hline
\end{tabular}

${ }^{2}$ In Expts. II-VI additional $\mathrm{P}$ added as $\mathrm{H}_{3} \mathrm{PO}_{4}$ to maintain $\mathrm{pH}$.

concentrations were evident for Expts. III-VI (Table 6). The lower final solution concentrations found in Expt. VI probably resulted from greater plant uptake from additional plug trays present in the ebb and flood bench in this experiment.

The temperature data in Table 6 show fairly uniform air and plug medium temperatures over time. The heating setpoints were $18 / 23 \mathrm{C}$ night/day and the cooling set points were 19/24C. The air in Expts. II-VI averaged between 18.5 and $18.9 \mathrm{C}$ at night and between 23.0 and 23.1C during the day. In Expt. I, higher air temperatures resulted from high ambient temperatures in the surrounding greenhouse. If these data are averaged over the six experiments, the following conclusions can be drawn: 1) day air temperature averaged $4.2 \mathrm{C}$ higher than night; 2 ) at night, LI and $\mathrm{HI}$ plug medium temperatures were 1.1 and $2.0 \mathrm{C}$ higher than the air temperature, respectively; 3) during the day, HI plug medium was $0.4 \mathrm{C}$ warmer than the air temperature while 
LI plug medium was $0.9 \mathrm{C}$ cooler; and 4) the HI plug medium was $0.9 \mathrm{C}$ warmer than the LI during the night and $1.3 \mathrm{C}$ during the day.

Nearly identical environmental and cultural conditions were apparent for Expts. III, IV, and V for irradiance, nutrition, and temperature; in addition, photoperiod was held constant at 24 $\mathrm{h}$ and $\mathrm{CO}_{2}$ was at ambient levels (340 to $380 \mu$ 1.liter ${ }^{-1}$ ).

The seedling stands observed under baseline conditions over time are reported below as percentages of total tray cells for Expts. I-VI, respectively: single seedling cells-81\%, 81\%, $78 \%, 71 \%, 77 \%$, and $73 \%$; multiple seedling cells-7\%, 7\%, $9 \%, 12 \%, 7 \%$, and $18 \%$. Low single seedling stands are coincident with high multiple seedling-stands; differences in seedling stands among experiments probably resulted from variable performance of the automated seeder in providing a single seed in each plug tray cell.

The shoot dry weight, height, and leaf area of seedlings produced under baseline conditions varied substantially (Table 7). Because seedlings in Expt. I were not sampled on Days 10, 13, 16 , and 19 as in the other experiments, we report predicted means that have been calculated by fitting an exponential growth model to the means reported in Table 4 . Predicted values were not included in the ANOVA examining treatment effects (i.e., among experiments). Significant differences in mean dry weights among experiments were found for the different seedling ages and irradiance levels. The shoot dry weights for the seedlings at the HI level were uniform among Expts. III, IV, and V; reduced shoot dry weights were found in Expts. I and II and the highest dry weight was in Expt. VI. Small but significant differences in LI dry weight are apparent among Expts. III, IV, and $\mathrm{V}$ for seedling ages of 10 and 19 days. Therefore, differences in dry weight growth for the period spanning Expts. III$\mathrm{V}$ were generally not significant. This outcome corresponds with the uniform conditions maintained during this period.

If differences in irradiance and temperature among experiments are ignored and if the predicted dry weights are accurate, the increased nutrient levels in Expt. II resulted in seedlings that were on average $35 \%$ heavier than in Expt. I (averaged for all ages and irradiance levels, dry weight increases ranged from $0 \%$ to $58 \%$ heavier). The seedling dry weight found in Expt. II compared with the mean dry weight from the subsequent three experiments (i.e., Expts. III, IV, and V) showed an average increase of $19 \%$ (increases ranged from of $2 \%$ to $28 \%$ ) for all ages and irradiance levels.

The additional irradiance resulting from the new lamps in Expt. VI caused little difference in shoot dry weight at the LI (from a $4 \%$ decrease to a $5 \%$ increase) compared with the mean dry weight from the previous three experiments; in the HI tray position, the additional PPF increased shoot weights from $14 \%$ to $28 \%$.

The shoot height results in Table 7 do not illustrate any particular pattern over time except that predicted heights from Expt. I are consistently shorter than the mean measured heights found in the later five experiments. A similar conclusion is apparent

Table 7. Shoot dry weight, height, and leaf area of impatiens seedlings under baseline conditions in Expts. I-VI.

\begin{tabular}{|c|c|c|c|c|c|c|c|c|}
\hline \multirow{2}{*}{$\begin{array}{l}\text { Seedling } \\
\text { age } \\
\text { (days) } \\
\end{array}$} & \multirow{2}{*}{$\begin{array}{c}\text { Irradiance } \\
\text { level }\end{array}$} & \multicolumn{6}{|c|}{ Experiment no. } & \multirow[b]{2}{*}{$\mathrm{LSD}^{y}$} \\
\hline & & $\mathrm{I}^{\mathrm{z}}$ & II & III & IV & $\mathrm{V}$ & VI & \\
\hline \multicolumn{9}{|c|}{ Mean shoot dry wt (mg) } \\
\hline \multirow[t]{2}{*}{10} & LI & 1.7 & $2.0 \mathrm{a}$ & $2.7 \mathrm{~d}$ & $2.3 \mathrm{ab}$ & $2.4 \mathrm{bc}$ & $2.6 \mathrm{~cd}$ & 0.3 \\
\hline & $\mathrm{HI}$ & 2.1 & $2.1 \mathrm{a}$ & $2.5 \mathrm{~b}$ & $2.6 \mathrm{~b}$ & $2.6 \mathrm{~b}$ & $3.1 \mathrm{c}$ & 0.4 \\
\hline \multirow[t]{2}{*}{13} & LI & 3.3 & $4.7 \mathrm{a}$ & $6.3 \mathrm{~b}$ & $5.8 \mathrm{~b}$ & $5.9 \mathrm{~b}$ & $6.0 \mathrm{~b}$ & 0.8 \\
\hline & HI & 4.2 & $5.4 \mathrm{a}$ & $6.6 \mathrm{~b}$ & $6.7 \mathrm{~b}$ & $7.0 \mathrm{~b}$ & $8.1 \mathrm{c}$ & 0.6 \\
\hline \multirow[t]{2}{*}{16} & LI & 6.6 & 10.4 & 13.6 & 11.3 & 11.6 & 11.7 & \\
\hline & $\mathrm{HI}$ & 8.6 & $13.3 \mathrm{a}$ & $15.0 \mathrm{~b}$ & $15.2 \mathrm{~b}$ & $14.4 \mathrm{ab}$ & $17.0 \mathrm{c}$ & 1.3 \\
\hline \multirow[t]{2}{*}{19} & LI & 13.2 & $18.0 \mathrm{a}$ & $22.4 \mathrm{bc}$ & $20.4 \mathrm{~b}$ & $22.8 \mathrm{c}$ & $22.4 \mathrm{bc}$ & 2.2 \\
\hline & $\mathrm{HI}$ & 17.6 & $26.3 \mathrm{a}$ & $26.8 \mathrm{a}$ & $26.5 \mathrm{a}$ & $27.4 \mathrm{a}$ & $34.4 \mathrm{~b}$ & 5.2 \\
\hline \multicolumn{9}{|c|}{ Mean shoot ht (mm) } \\
\hline \multirow[t]{2}{*}{10} & LI & 6.6 & $7.1 \mathrm{a}$ & $8.4 \mathrm{~b}$ & $7.3 \mathrm{a}$ & $7.0 \mathrm{a}$ & $7.6 \mathrm{a}$ & 0.7 \\
\hline & HI & 6.3 & $6.9 \mathrm{a}$ & $7.6 \mathrm{~b}$ & $6.6 \mathrm{a}$ & $6.6 \mathrm{a}$ & $7.5 \mathrm{~b}$ & 0.5 \\
\hline \multirow[t]{2}{*}{13} & LI & 8.3 & 10.4 & 10.2 & 9.3 & 10.2 & 9.8 & NS \\
\hline & HI & 8.1 & 10.2 & 9.6 & 9.4 & 10.0 & 9.8 & \\
\hline \multirow[t]{2}{*}{16} & LI & 10.5 & $10.9 \mathrm{a}$ & $13.4 \mathrm{c}$ & $11.7 \mathrm{ab}$ & $12.6 \mathrm{bc}$ & $12.6 \mathrm{bc}$ & 1.1 \\
\hline & HI & 10.5 & $11.4 \mathrm{a}$ & $12.7 \mathrm{~b}$ & $12.9 \mathrm{~b}$ & $13.3 \mathrm{~b}$ & $13.7 \mathrm{~b}$ & 1.1 \\
\hline \multirow[t]{2}{*}{19} & LI & 13.3 & 15.3 & 17.9 & 15.5 & 17.2 & 16.2 & NS \\
\hline & HI & 13.6 & 16.8 & 17.7 & 16.3 & 18.3 & 19.5 & NS \\
\hline \multicolumn{9}{|c|}{ Mean leaf area $\left(\mathrm{mm}^{2}\right)$} \\
\hline \multirow[t]{2}{*}{12} & LI & 140 & 100 & 130 & 100 & 150 & 130 & --- \\
\hline & HI & 150 & 110 & 150 & 140 & 150 & 140 & $\cdots$ \\
\hline \multirow[t]{2}{*}{15} & LI & 210 & 240 & 310 & 290 & 270 & 220 & --- \\
\hline & $\mathrm{HI}$ & 230 & 230 & 290 & 290 & 290 & 330 & --- \\
\hline \multirow[t]{2}{*}{18} & LI & 310 & 380 & 740 & --- & 580 & 510 & --- \\
\hline & HI & 330 & 440 & 580 & --- & 670 & 500 & --- \\
\hline \multirow[t]{2}{*}{21} & LI & 460 & 550 & 870 & --- & --- & --- & --- \\
\hline & HI & 490 & 620 & 810 & --- & --- & --- & --- \\
\hline
\end{tabular}

${ }^{2}$ Predicted means from exponential growth models.

${ }^{\mathrm{Y}}$ Least significant difference $(\mathrm{P}=0.05)$ for treatment effects (Expts. II-VI) if ANOVA significant $(\mathrm{P}<0.05)$; mean separation in rows based on sSD at $\mathrm{P}=0.05$. Lack of replication within irradiance levels for leaf area prevented ANOVA calculation. 
for the leaf area data (Table 7) for the older seedlings (18 and 21 days). The lack of trends in height and leaf area may result from larger measurement errors for these characteristics. The height measurements have considerable error imposed by judgment of topmost petiole location and by inconsistent cutting of the stem at ground level. The leaf area measurements also involve appreciable error because of difficulties encountered with the detachment of small leaves and cotyledons from small seedlings and the placement and removal of numerous succulent, small leaves from the leaf area meter belt.

The consistent shoot dry weight growth observed in Expts III, IV, and V, when nearly identical environmental conditions were imposed, lends credence to the proposition that predictable and repeatable seedling growth can be obtained among experiments over time.

Our results serve as a case study examining growth response uniformity obtained among discrete experimental units and over time spanning many experiments. Despite the unsophisticated design of these growth rooms in comparison with many manufactured or fabricated growth chambers, uniform growth responses were found when nearly identical conditions were maintained.

For researchers contemplating similar experimental designs, these results illustrate problems that may arise in the course of such studies. Some of the variation in environmental conditions resulted from phenomena that were known at the start of the experiments (e.g., the degradation in lamp output over time). Other variable conditions became apparent later; the nonuniform nutrient charge was an unexpected complication that resulted in advertent changes in nutrient levels. Even with numerous pilot experiments, we still had to confront and resolve changes in environmental and cultural conditions during this series of experiments. Despite the complications in doing sequential experiments, the results of this study should offer hope to other researchers that this experimental approach can produce satisfactory data.

\section{Literature Cited}

Buck, J.A. 1973. High intensity discharge lamps for plant growth applications. Trans. Amer. Soc Agr. Eng. 16(1):121-123.

Canham, A.E. 1971. The growing room in commercial horticulture. Acta Hort.22:156-163.

Dreesen, D.R. 1988. Effects of irradiance, photosynthetic photoperiod, temperature, and carbon dioxide level on the production of impatiens plug seedlings in controlled environment growth rooms. $\mathrm{PhD}$ Diss., Cornell Univ., Ithaca, N.Y.

Hammer, P.A., T. W. Tibbitts, R.W. Langhans, and J.C. McFarlane. 1978. Base-line growth studies of 'Grand Rapids' lettuce in controlled environments. J. Amer. Soc. Hort. Sci. 103(5):649-655.

Krizek, D. T., W.A. Bailey, H.H. Klueter, and H.M. Cathey. 1968. Controlled environments for seedling production. Proc. Intl. Plant Prop. Soc. 18:273-281.

Krizek, D. T., W.A. Bailey, H. Klueter, and R.C. Liu. 1974. Maximizing growth of vegetable seedlings in controlled environments at elevated temperature, light, and $\mathrm{CO}_{2}$. Acta Hort. 39:89-101.

Miller, R. 1989. Phytofarms: the ultimate in controlled environments. GrowerTalks 52(12):22-30.

Minitab, Inc. 1988. Minitab reference manual-release 6. Minitab, Inc., State College, Pa.

Snedecor, G.W. and W.G. Cochran. 1980. Statistical methods. 7th ed. Iowa State Univ. Press, Ames.

Sokal, R.R. and F.J. Rohlf. 1969. Biometry. W.H. Freeman, San Francisco. 